\title{
Analysis of Tax Reforms among Salaried Assessees: A Case Study of Tamil Nadu
}

\author{
A. Jayakumar* and R. Elavarasan**
}

\begin{abstract}
This paper focuses on the impact of tax reforms among salaried assessees in Tamil Nadu. The aim of the paper is find out whether and how tax reforms affect the level of salaried assessees. Using convenience sampling method, the primary data was analysed with the help of descriptive statistics. Chi square test and Anova test were used to test if significant relationship exists between assessees' personal information and opinion level of tax allowances. The respondents were asked to indicate their level of agreement with a given statement on a likert five point scale. The results shows that, overall the assessees have negative opinion towards impact of tax reforms in India.
\end{abstract}

Keywords: Tax Reforms, Taxation, Direct Tax, Salaried Assessees, Deductions, Exemption.

\subsection{Introduction}

The primary purpose of a tax system is to collect the revenue needed to fund the operations of the union government including its promises and commitments. Tax revenues may not fully match the government spending each year but over time, the Union government needs to be able to raise sufficient revenue to cover its current and expected financial obligations. Decisions about spending and the role of government have a direct impact on the governments ultimate revenue needs (Walker, 2005). Tax reform invariably forms a key component of structural adjustment programmes of developing countries and for good reasons. The most important reason is that when a country undertakes to reform its economic structure to overcome chronic macroeconomic imbalances and remove impediments to growth, it is imperative to bring the tax system too in line with the basic thrust of the structural reforms.

*Professor, Department of Commerce, Periyar University, Tamil Nadu.

**ICSSR Doctoral Fellow, Department of Commerce, Periyar University, Tamil Nadu. 
A basic tenet that has guided our tax reforms, as those of many other countries in recent years has been 'widening the base, reducing the rates'. The aims of equity, efficiency and simplicity are served best, it is argued, when the base of the tax is comprehensive, be it income or consumption. In a regressive tax system, lower income tax payers pay larger percentage of income in taxes compared to higher income taxpayers. This study is an endeavour to discuss the trends and patterns of tax systems, particularly salaried people, their impact and determinants of Indian economy. A study of Income Tax Act 1961, which is now over five decades old, will be undertaken. The Act has gone through several changes through the Finance Acts, Government notifications and judicial rulings that have made the Income tax law a complicated and one may add, an irrelevant mess. (Lall, 1982). The study tries to highlight the changing tax provisions and its impact on salaried group of people in Tamil Nadu and presents the experience of tax reforms among salaried people in India.

\subsection{Literature Review}

The literature on tax reforms and a comparative picture of personal income taxes across countries is meagre, presumably because of the inherent difficulties associated with attempting such an exercise. According to Pant (2012), the New Direct Tax Code which was said to be introduced from the financial year, 2012-13 replacing the five decade old Income tax Act, 1961 has the objective to make the Indian tax structure straightforward. The Income Tax Act 1961 has become very complex and virtually unintelligible to the common man by virtue of a complicated structure, numerous amendments, frequent policy changes and a multitude of judgments that gave varying interpretations to already undecipherable provisions. This complexity has not only increased the cost of compliance for the average tax payer, but also made it costly for the administration to collect tax. For the replacement of Income Tax 1961, the new Direct Tax Code which is completely new gives moderate relief to tax payers, reduce unnecessary exemptions and improve compliance for improving collections. The tax payers themselves can compute and file Income Tax Returns without the help of experts. This paper highlights the overview of the Direct Taxes Code in a nutshell.

Singh (2012) reviewed the fiscal developments which had taken place during the post liberalisation period as a result of economic reforms introduced during the period. He focused specifically on the impact of tax reforms in general and direct taxes in particular on the fiscal situation. He identified the annual growth rates of direct taxes for the period 1991- 92 to 2000-2001; the results revealed that the direct tax revenues on an average grew at $20.53 \%$ p.a., average growth rate of corporation tax and income tax and 
income tax during the above period was at 21.46 and $19.92 \%$ respectively. In a nutshell the growth in the direct taxes of all types is not consistent during the period. The upper rich class has further benefited during the post reform period.

Bagchi (2011) observed that tax reform invariably forms a key component of structural adjustment programmes of developing countries and for good reasons. The most important reason is that when a country undertakes to reform its economic structure, it is imperative to bring the tax system too in line with the basic thrust of the structural reforms, enhancing efficiency in the allocation and use of resources by promoting competition and avoiding needless interference with market forces. For various reasons arising from administrative deficiencies and problems inherent in the structure of their economy, governments in less developed countries in general had come to rely more on taxes on foreign trade and a medley of taxes on domestic production and trade than on taxes on income or capital to meet their revenue needs. While progressive taxation of income was practiced, its contribution to revenue has seldom been substantial. Evasion was widespread and the laws were riddled with loopholes. On the other hand, the system of indirect taxation prevalent in these countries rarely followed any rational pattern, having evolved mainly out of changes made from time to time in response to exigencies of revenue needs of the government.

Biswas (2009) in his article on the impact of inflation on personal income tax India argued that it is not the case that income tax has totally ignored the effect of inflation. He showed that the exemption limit has moved up more than was necessary to neutralise the inflationary impact. He also looked at the ratio of the exemption limit to per capita income for 21 selected countries and find that the ratio is highest for India followed by Pakistan and Australia, West Germany and Israel. The author also recognises that exemption limit of personal income tax must depend upon the mix between direct and indirect taxes amongst countries.

\subsection{Theoretical Issues in Tax Reform}

How should a tax system be designed to raise a given amount of revenue? More specifically, what criteria should be used to evaluate the advantages and disadvantages of a particular tax system or a particular tax policy proposal? The answers matter because various combinations of tax bases and rates can raise the same amount of revenue. Tax system design is a matter of judgment about how to best balance:

- Equity

- Economic efficiency and

- Simplicity, Transparency and Administration 
The positive theory of taxation suggests that the particular features of the developing countries require different tools of analysis and structure of the models. Some of the special features of the developing countries for tax analysis includes:

i) Predominant primary sector;

ii) Economic and social dualism;

iii) Segmentation of labour and capital markets;

iv) High poverty and inequality;

v) Planning and economic regulation; and

vi) Corruption and tax evasion.

The personal income tax in most developing countries is neither global nor, in many cases, very progressive. In practice such taxes often amount to little more than a set of incomplete and inconsistent rules applicable to different types of income (Bird \& Zolt 2005). It is thus not surprising that personal income taxes play a very limited role in developing countries. Many developing countries subject income from capital to relatively low effective tax burdens under the personal income tax system through policy design, poor tax administration or both.

1. Abandon the income tax

2. Comprehensive income tax

3. Flat income tax

4. Dual income tax

\subsection{Statement of the Problem}

The Income Tax Act, 1961 which has been effective from $1^{\text {st }}$ April 1962, has been followed by Tax Administrators and Tax Payers till now, with due amendments taking place every year. This Act consists of 298 Sections, sub-sections, rules and sub-rules running into several pages by way of Income Tax Provisions for computing and levying of tax under various circumstances. In a regressive tax system, lower income taxpayers pay larger percentages of their incomes in taxes compared to higher income taxpayers, although most of the policymakers and citizens view regressive taxation as generally unfair and unethical. The study is an endeavour to discuss the trends and patterns of tax systems and the impact of tax reforms on salaried class. The study tries to highlight the impact of changing tax provisions on salaried assessees in Tamil Nadu and also presents the experience of first generation of tax reforms impact on the head 'Salaries'. Thus, the objectives of the study can be stated as follows: To study the concept of tax reforms of direct taxes.

- To know the level of awareness of the tax reforms among the salaried assessees. 
- To analyse the impact of tax reforms on salaried assessees in Tamil Nadu. In line with the objectives, the following hypotheses have been stated:

Ho $_{1}$ - There is no association between assessees personal information and fully taxable allowance of the respondents and benefited level on the tax reform.

Ho$_{2}$ - There is no association between assessees personal information and partly exempted allowance of the respondents and benefited level on the tax reform.

The present study is a pilot study for salaried assessees in Tamil Nadu. A true representation about tax reforms will require a larger and broader sample. We hope to give some valuable information for improvements in the Indian tax system.

\subsection{Research Methodology}

The survey method has been followed for the study. Both primary and secondary sources of data have been used. A well-structured questionnaire has been designed to elicit necessary data and details from the salaried assessees. The secondary data has been collected from the books, journals, reports, magazines and web portals. A convenience non-random sampling method is employed to elicit the necessary information from the salaried assessees in Tamil Nadu and 100 respondents were selected from the universe.

The primary data collected from the respondents has been analysed with the help of Statistical Package for Social Sciences (SPSS). The various statistical tools, such as Descriptive Statistics, Parametric one-sample ' $t$ ' test, one-way Analysis of Variance (ANOVA), Non-parametric Chi-square test are used for this study.

\subsection{Results and Analysis}

\subsection{Awareness level of tax reforms}

\section{Descriptive Analysis}

Descriptive analysis also termed as percentage analysis were performed for each question contained in the interview schedule mainly to ascertain the distribution of the respondents in each category. In this section, the information relating to the personal information of the respondents was analysed. The personal information of the respondents considered for the analysis are age, gender, marital status, educational qualification, designation, gross total income.

\section{Employment wise-classification}

The Employment wise-classification of the respondents is given in Table 1. The Table depicts that employment in state Govt. and Private was about 50 and 28 respectively. 
The number of respondents employed in public sector and Central govt. were 14 and 8 respectively.

Table 1: Employment-wise Distribution of Respondents

\begin{tabular}{|c|c|c|}
\hline Employer Status & Frequency & Cumulative percentage \\
\hline Central Govt. & 08 & 8.0 \\
\hline State Govt. & 50 & 58.0 \\
\hline Public sector & 14 & 72.0 \\
\hline Private & 28 & 100 \\
\hline
\end{tabular}

The respondents are given opportunity to express their transparent opinion on existing tax rates in the Indian economy conditions as well as its nature of severity. Table 2 gives the distribution of the opinion of assesses about existing tax rates. It clearly describes the ambiguity of opinion on existing tax rates. 54\% of the respondents feel that tax rates are low to moderate. However, about $46 \%$ of the respondents feelt hat tax rates are high or very high.

Table 2: Opinion of Assessees about Prevailing Tax Rates

\begin{tabular}{|c|c|c|c|}
\hline $\begin{array}{c}\text { Opinion about } \\
\text { Tax rate }\end{array}$ & Frequency & Percent & Cumulative Percent \\
\hline Low & 14 & 14.0 & 14.0 \\
\hline Moderate & 40 & 40.0 & 54.0 \\
\hline High & 30 & 30.0 & 84.0 \\
\hline Very High & 16 & 16.0 & 100 \\
\hline Total & $\mathbf{1 0 0}$ & $\mathbf{1 0 0}$ & \\
\hline
\end{tabular}

The respondents were then asked if they felt the burden/pinch of current tax slabs. The level of burden of current slab rates is included as one of the profile variables in the study. Table 3 shows the distribution of respondents in terms of whether they have felt the burden of existing tax slabs or not. The results show that $72 \%$ of the respondents agreed to having felt the burden of existing tax slabs on their income while a low $28 \%$ did not feel so. 
Table 3: Opinion of Assessees about Burden of Current Tax Slabs

\begin{tabular}{|l|l|l|l|}
\hline $\begin{array}{l}\text { Is current slab } \\
\text { burdensome? }\end{array}$ & Frequency & Percent & Cumulative Percent \\
\hline Yes & 72 & 72 & 72 \\
\hline No & 28 & 28 & 100 \\
\hline Total & 100 & 100 & \\
\hline
\end{tabular}

Table 4 shows the distribution of respondents according their awareness level about the concept of tax evasion and tax avoidance. As seen from the Table 4, 60\% of the respondents were aware of the concept and extent of tax evasion and avoidance while $40 \%$ were not.

Table 4: Awareness of the Concept of Tax Evasion and Avoidance

\begin{tabular}{|c|c|c|c|}
\hline $\begin{array}{l}\text { Awareness of the concept of Tax } \\
\text { evasion and Avoidance }\end{array}$ & Frequency & Percent & $\begin{array}{l}\text { Cumulative } \\
\text { Percent }\end{array}$ \\
\hline Yes & $\mathbf{6 0}$ & 60.0 & 60.0 \\
\hline No & 40 & 40.0 & 100.0 \\
\hline Total & 100 & 100.0 & \\
\hline
\end{tabular}

\subsection{Levels of expectation of future reform on direct tax}

Table 5 describes the level of expectations of future reforms on direct taxes stated by the respondents and the motivation factors. The important factors which determine the level of expectation include increase in 80C -80U deduction limit, concessional provision of Tax Planning Handbook, and separate rate schedule.

Table 5: Friedman Test indicating factors influencing the Levels of expectations regarding Future Reforms on Direct Taxes

\begin{tabular}{|l|r|r|r|}
\hline \multicolumn{1}{|c|}{ Factor } & \multicolumn{1}{|c|}{ Mean } & Standard deviation & Std. error mean \\
\hline $\begin{array}{l}\text { 80C -80U Deduction limit } \\
\text { should be increase }\end{array}$ & 1.6200 & .83029 & .11742 \\
\hline $\begin{array}{l}\text { Guidelines of the tax Planning } \\
\text { Handbook Provide by the } \\
\text { Govt. at the concessional rate }\end{array}$ & 1.8000 & .78246 & .11066 \\
\hline $\begin{array}{l}\text { Do you expect a separate rate } \\
\text { schedule for salaried class }\end{array}$ & 1.7800 & .93219 & .13183 \\
\hline
\end{tabular}


Table 6 shows the results of the chi-square test to test the association between the satisfaction level on the job and opinion on fully taxable allowances like basic salary, dearness allowances, tiffin allowances, deputation allowances.

$\mathrm{Ho}_{1}$ - There is no association between assessees personal information and fully taxable allowance of the respondents and benefited level on the tax reform.

The p-value for the all other demographic variables is greater than 0.05 and hence the result is not significant at 5\% level. The Chi square result shows that the at $5 \%$ level of significance, there is no significant relationship between assessees' information and fully taxable allowance factors the level of the respondents. Hence the hypothesis is accepted.

Table 6: Results of Chi-Square Test

\begin{tabular}{|l|c|c|c|}
\hline \multicolumn{1}{|c|}{ Factors } & Value & Df & Asymp. Sig. (2-sided) \\
\hline Age & 2.897 & 3 & $\mathbf{. 4 0 8}$ \\
\hline Employer & .490 & 3 & $\mathbf{. 9 2 1}$ \\
\hline Gross Total Income & 3.704 & 2 & $\mathbf{. 1 5 7}$ \\
\hline Education & 1.687 & 3 & $\mathbf{. 6 4 0}$ \\
\hline
\end{tabular}

Table 7 gives the results of Analysis of Variance (ANOVA) test to see if there is a significant difference between mean scores with respect to various factors. It tests for the significance of difference between the opinions levels on partly exempted allowances in the taxable salary. The ANOVA procedure is used to compares mean scores of more than two groups. The procedure assumes that the variances of the groups are equal and it was tested. The significant difference between the mean scores is tested with respect to the various factors like House rent allowance, Entertainment Allowance, Children Education Allowance, Hostel Expenditure Allowance (His Child), Conveyance Allowance.

$\mathrm{Ho}_{2}$-There is no significant difference between assessees personal information and partly exempted allowance of the respondents and benefited level on the tax reform.

The results in Table 7 show the descriptive statistics of the sample size, mean and standard deviation. The p-value of the calculate value $\mathrm{F}(.723, .958, .177, .568)$ is more than the significance level of 5\%, hence we accept the null hypothesis. There is no significant difference between assessees' information and partly exempted allowance.

\subsection{Summary of findings}

This study aimed at analysing the impact of tax reform among salaried assessees in Tamil Nadu. There are various factors like changing provision of salary, allowances, 
perquisites, exemptions, deductions, rebate and uses which influence the expectations and opinion regarding tax reforms in Indian tax systems.

Table 7: Results of ANOVA test

\begin{tabular}{|c|c|c|c|c|c|c|}
\hline \multicolumn{2}{|c|}{ Allowances Factors } & $\begin{array}{c}\text { Sum of } \\
\text { Squares }\end{array}$ & d.f & $\begin{array}{c}\text { Mean } \\
\text { Square }\end{array}$ & $\mathbf{F}$ & Sig \\
\hline $\begin{array}{l}\text { Age of the } \\
\text { Assessees }\end{array}$ & $\begin{array}{l}\text { Between } \\
\text { Groups } \\
\text { Within } \\
\text { groups } \\
\text { Total }\end{array}$ & $\begin{array}{c}.084 \\
31.536 \\
31.620\end{array}$ & $\begin{array}{l}1 \\
48 \\
49\end{array}$ & $\begin{array}{l}.084 \\
.657\end{array}$ & .127 & .723 \\
\hline $\begin{array}{l}\text { Education } \\
\text { criteria }\end{array}$ & $\begin{array}{l}\text { Between } \\
\text { Groups } \\
\text { Within } \\
\text { groups } \\
\text { Total }\end{array}$ & $\begin{array}{l}.003 \\
55.99 \\
56.00\end{array}$ & $\begin{array}{l}1 \\
48 \\
49\end{array}$ & $\begin{array}{l}.003 \\
1.167\end{array}$ & .003 & .958 \\
\hline $\begin{array}{l}\text { Gross } \\
\text { Total } \\
\text { Income } \\
\text { p.a. }\end{array}$ & $\begin{array}{l}\text { Between } \\
\text { Groups } \\
\text { Within } \\
\text { groups } \\
\text { Total }\end{array}$ & $\begin{array}{l}.561 \\
14.31 \\
14.88\end{array}$ & $\begin{array}{l}1 \\
48 \\
49\end{array}$ & $\begin{array}{l}.561 \\
.298\end{array}$ & 1.88 & .177 \\
\hline $\begin{array}{l}\text { Status of } \\
\text { Employer }\end{array}$ & $\begin{array}{l}\text { Between } \\
\text { Groups } \\
\text { Within } \\
\text { groups } \\
\text { Total }\end{array}$ & $\begin{array}{l}.291 \\
42.21 \\
42.50\end{array}$ & $\begin{array}{l}1 \\
48 \\
49\end{array}$ & $\begin{array}{l}.291 \\
.879\end{array}$ & & \\
\hline
\end{tabular}

In general, the findings can be summarised as below:

- Majority (48\%) of the assessees are belongs to the age group of 30-40 years.

- Majority (56\%) of the assessees have 'salary' as their only source of income

- Most $(62 \%)$ of the assessees belongs to Gross total income group of up to Rs. $5,00,000$ p.a.

- $64 \%$ of the assessees favour reduction in existing tax rates.

- $42 \%$ of the assessees feel the Pinch of current slabs.

- $60 \%$ of the assessees are aware about the concept and extent of tax evasion and tax avoidance. 
- $68 \%$ of the assessees desire increase in the deductions limit 80CCE from Rs.1lakh to Rs. 2,50,000.

- A majority of the respondents strongly agreed to the concept of "Tax reforms made me more conservative".

- $56 \%$ of the respondents agreed to the statement of "I closely watch the tax reforms to reduce my tax liability".

- $46 \%$ of the respondents strongly agreed to the concept of "Tax reforms induced me to spend more".

- $56 \%$ of the respondents are neutral to the concept of "I am confused because of many tax reforms".

- $62 \%$ of the respondents strongly agreed to the concept of "I try my best to avoid tax".

- $58 \%$ of the respondents are neutral to the concept of "Tax evasion is only way to reduce my tax liability".

- $82 \%$ of the respondents strongly agreed to the concept of "I am fully availing the tax exemption and deductions to reduce my tax liability".

\subsection{Conclusion}

In India, the system of direct taxation has been in force since ancient times. According to Arthashastra, Manu laid down that traders and artisans should pay $1 / 5^{\text {th }}$ of their profits in silver and gold, while the agriculturists were to pay $1 / 6^{\text {th }}, 1 / 8^{\text {th }}$ and $1 / 10^{\text {th }}$ of their produce depending upon their circumstances. Nowadays, as per the Income Tax Act 1961, income tax levied by the Central government at the rate of 33\% collected from the source of salary seems a bit unfair. This study conducts a primary survey for salaried assessees in Tamil Nadu and finds that most of the respondents feel that income tax rates prevailing in India are high. This study reveals that maximum number of the salaried assessees desire improvements in tax deductions and exemptions to the salaried taxpayers. The study gives suggestions and recommendations which could provide inputs for more efficient and equitable tax administration.

\section{References}

Archarya, Shankar. (2005). Thirty Years of Tax Reform in India. Special article, Economic and Political Weekly, May 14: 2061-2069. 
62 |VISION: Journal of Indian Taxation, Volume 2, Issue 1

Bernhardt, K, (1997). Rents, Taxes, and Peasant Resistance: The Lower Yangzi Region, 1840-1950. Stanford, CA: Stanford University Press.

Bird, R, \& Zolt, E, (2005). Redistribution via taxation: The limited role of the personal income tax in developing countries. UCLA Law Review, 52(6): 1627-1695.

Chen, X, (2003). A Study on China's County and Township Public Finance and Farmers' Income Growth. Shangxi Economic Press.

Das Gupta, Arindam (2005). Recent individual income tax reform. Economic and Political Weekly, 1397-1405.

Douglas, holtz-eakin. (1996). Fundamental tax reform and state and local governments. National Tax Journal, 49 (3): 475-86.

Gravelle, Jane, (1995). The Flat Tax and Other Proposals: Who Will Bear the Tax Burden. Tax Notes 69 (12): 1517-27.

Jayakumar, A., \& Dhanapal, C. (2006). Income Tax: Theory, Law and Practice: Assessment Year 2006-2007. Learn tech press.

Jhaveri, (2002). Direct Tax Reform: A Critical Evaluation of the Task Force Paper. Economic and Political Weekly, 37(48): 4765-4770.

Jhaveri, (2005). Direct Tax Reform: A Critical Evaluation of the Task Force Paper. Economic and Political Weekly, 37(48): 4765-4770.

Lall, V. D. (1982). Direct taxes on individual and business income: Economic implications and impact. Economic and Political Weekly, 17(12): 451-458.

Pant, Kamal \& Arya, Ashish. (2012). Assessee perception towards Direct Tax Code. International Journal of Management \& Business Studies, 2(2): 51-54 .

Rao, Govinda. (2005). Tax system reform in India: Achievements and challenges ahead. Journal of Asian Economics, 16: 93-1011. 
Analysis of Tax Reforms among Salaried Assessees: A Case Study of Tamil Nadu | 63

Sidhu, Amarjit Singh. (2003). Direct tax reforms in India: Post liberalization scenario. Sree Niwas Publications, 206-222.

Singhania, Vinod K, \& Singhania, Kapil. (2013). Direct Taxes: Law and Practice, Assessment Year 2014-2015, Taxmann Publications (P.) Ltd.

Walker, M, (2005). Understanding the Tax Reform Debate: background, Criteria and Questions. U.S Government Accountability Office, Sep: 2005. 